\section{Tobacco: a threat to development?}

\author{
Ruth E Malone, ${ }^{1}$ Joshua S Yang ${ }^{2}$
}

In keeping with the broader understanding that tobacco is not merely a threat to individual health but to the cause of social and environmental justice, the theme for World No-Tobacco Day this year is Tobacco: A threat to development. Here it is important to first differentiate the type of development that advances the health of individuals, communities and ecosystems versus the type of development that exploits and harms them. The term 'development' as it has been used historically in the social sciences is itself fraught with ambiguity and inconsistency. ${ }^{1}$

Traditionally, the term has usually included an element of maturation of economies and economic industries so people can move out of the non-wage sector into more productive and prosperous wage sectors. Over time, 'development' has been broadened to address human development, including health, literacy, democracy, human rights and other non-economic domains. Nevertheless, the dominant, often implicit, interpretation of 'development' is of economic development or the development of economic systems to meet human development goals.

Though the proportion of the world's population living in poverty has declined since 1990, ${ }^{2}$ 'development' has resulted in increasing inequality and a consolidation of wealth and power among economic and political elites, with neoliberalism the dominant model for pursuing economic growth and development since the 1970s. ${ }^{3}$ For local communities, the result is often exploitation of human and natural resources and public goods, ${ }^{4}$ and exclusion from the benefits of economic growth. An uncritical embedding of global health within a development agenda can also lead to an over-reliance on economic principles and tools-such as fostering individual choice and market mechanisms-to achieve health goals. Both of these may favour the corporate agenda of Big Tobacco, undermining the critical role of strong regulations to protect the public.

\footnotetext{
'Department of Social and Behavioral Sciences, University of California, San Francisco, California, USA ${ }^{2}$ Department of Health Science, College of Health and Human Development, California State University, Fullerton, California, USA
}

Correspondence to Professor Ruth E Malone, Department of Social and Behavioral Sciences, School of Nursing, University of California, San Francisco 94118, California, USA; ruth.malone@ucsf.edu
'Sustainable' development has been defined as 'development that promotes prosperity and economic opportunity, greater social well-being and protection of the environment.' ${ }^{5}$ Overall, research shows that the business of tobacco is simply not compatible with such a vision. First, tobacco does not promote widespread prosperity. While economic boons accrue to some, the burdens are disproportionately distributed among nations and groups already suffering from higher rates of disease, poverty and marginalising factors. ${ }^{6}$ Admittedly, in some areas, government subsidies and the ability of growers to time the tobacco market through curing make tobacco a profitable crop for small numbers of farmers, but in many regions, farmers accrue net losses due to their inability to set fair prices, their need for advance funding to buy supplies and the advantages of large buyers who exert control over supply chains. ${ }^{7}$

Tobacco use is associated with increased poverty and food insecurity among both farmers and users as land formerly used to grow food crops is converted to tobacco growing and limited funds are used to buy addictive tobacco products instead of food. ${ }^{8}$ Tobacco users are poorer than non-users and more likely to report food insecurity, even in wealthier countries. ${ }^{9}$ While few studies measure overall social well-being in relation to tobacco, child welfare is an important measure of societal health. Despite several so-called 'corporate social responsibility' initiatives sponsored by tobacco companies, tobacco continues to be produced using child labour in unsafe conditions. ${ }^{710}$ In one study, higher levels of family unhappiness were reported by children in families where smoking occurred. ${ }^{11}$ At the level of individuals, there is evidence that those who do not use tobacco or who have quit are happier than those who continue to smoke. $^{12}$

Finally, tobacco is an environmentally destructive industry. ${ }^{13}$ In addition to deforestation for tobacco growing and curing, heavy use of pesticides contributes to water and soil pollution and degradation. Recent research has also called attention to the potential negative effects of leachate from billions of discarded cigarette butts on marine life. ${ }^{1415}$

Including tobacco control as a development issue can restore the humanity of the development agenda, moving beyond a focus solely on economic growth. The evidence for tobacco control as an important investment in development is clear: The macroeconomic costs of tobacco use can be avoided, the pain and suffering of tobacco-related diseases can be reduced and the relationship between tobacco use and poverty can be broken. ${ }^{16}$ Strong tobacco control measures can help raise the standard of living of families and communities and enable them to realise their aspirations and potential. In addition, tobacco control measures may reinforce the importance of embedding economic activity within the principles of a society that values human dignity and serves the common good. ${ }^{17}$ The interests of powerful, transnational economic entities should not be prioritised over the general welfare, whether it be tobacco companies or other actors, which exploit the public for private gain. Eliminating the tobacco threat by implementing tobacco control measures will help countries achieve the sustainable development goals. ${ }^{16}$

Competing interests None declared.

Provenance and peer review Not commissioned; internally peer reviewed.

(C) Article author(s) (or their employer(s) unless otherwise stated in the text of the article) 2017. All rights reserved. No commercial use is permitted unless otherwise expressly granted.

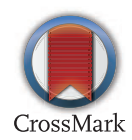

To cite Malone RE, Yang JS. Tob Control 2017;26: 241-242.

Tob Control 2017;26:241-242.

doi:10.1136/tobaccocontrol-2017-053773

\section{REFERENCES}

1 Cullather N. Development? It's history. Diplomatic History 2000;24:641-53.

2 World Bank. Poverty. 2016. http://dataworldbankorg/ topic/poverty

3 Harvey D. A brief history of neoliberalism. New York: Oxford University Press, 2005.

4 Harvey D. The "New" Imperialism: On Spatiotemporal Fixes and Accumulation by Dispossession. In: Panitch L, Leys C, eds. The new imperial challenge: socialist register 2004. London: Merlin Press, 2003.

5 United Nations. Promote sustainable development. 2017. http://wwwunorg/en/sections/what-we-do/ promote-sustainable-development/index.html

6 Callard C. Follow the money: how the billions of dollars that flow from smokers in poor nations to companies in rich nations greatly exceed funding for global tobacco control and what might be done about it. Tob Control 2010;19:285-90.

7 Hu TW, Lee AH. Tobacco control and tobacco farming in African countries. J Public Health Policy 2015:36:41-51.

8 WHO. Tobacco increases the poverty of individuals and families. 2017. http://www.hoint/tobacco/ 


\section{Editorial}

communications/events/wntd/2004/tobaccofacts families/en/

9 Kim JE, Tsoh JY. Cigarette Smoking among socioeconomically disadvantaged young adults in Association with Food Insecurity and other factors. Prev Chronic Dis 2016;13:E08.

10 Otañez M, Glantz SA. Social responsibility in tobacco production? tobacco companies' use of green supply chains to obscure the real costs of tobacco farming. Tob Control 2011;20:403-11.

11 Chen JJ, Ho SY, Au WM, et al. Family smoking, exposure to secondhand smoke at home and family unhappiness in children. Int I Environ Res Public Health 2015;12:14557-70.
12 Stickley A, Koyanagi A, Roberts B, et al. Smoking status, nicotine dependence and happiness in nine countries of the Former Soviet Union. Tob Control 2015;24:190-7.

13 Lecours N, Almeida GE, Abdallah JM, et al. Environmental health impacts of tobacco farming: a review of the literature. Tob Control 2012;21:191-6.

14 Booth DJ, Gribben P, Parkinson K. Impact of cigarette butt leachate on tidepool snails. Mar Pollut Bull 2015;95:362-4.

15 Slaughter E, Gersberg RM, Watanabe K, et al. Toxicity of cigarette butts, and their chemical components, to marine and freshwater fish. Tob Control 2011;20(Suppl 1):i25-9.
16 US National Cancer Institute, World Health Organization. The Economics of Tobacco and Tobacco Control, National Cancer Institute Tobacco Control Monograph 21 NIH Publication No. 16-CA-8029A. Bethesda, MD, USA: US Department of Health and Human Services, National Institutes of Health, National Cancer Institute and Geneva, World Health Organization, 2016

17 Abdelal R, Ruggie JC. The principles of embedded liberalism: Social legitimacy and global capitalism. In: Moss D, Cisternino J, eds. New perspectives on regulation. Cambridge, MA: The Tobin Project, 2009 